DOI: $10.19195 / 2084-5065.50 .10$

\title{
Prawno-kryminalistyczna problematyka przesłuchania małoletniego w procedurach prawnych
}

\author{
IWONA ZIENIEWICZ \\ ORCID: 0000-0002-3999-3543 \\ Katedra Kryminalistyki, Wydział Prawa, \\ Administracji i Ekonomii Uniwersytetu Wrocławskiego
}

Problematyka osobowych środków dowodowych, w tym zeznania świadka i proces ich powstawania, ma charakter interdyscyplinarny i jest przedmiotem licznych publikacji z zakresu prawa, psychologii, medycyny czy kryminalistyki. Dorobek tych nauk może być i jest wykorzystywany do doskonalenia procedur prawnych dotyczących taktyki odbierania zeznań od świadka, rozumianej jako sposób postępowania prowadzący do osiągnięcia zamierzonego celu ${ }^{1}$, którym z jednej strony jest uzyskanie wiarygodnych informacji, a z drugiej - jego ochrona przed negatywnymi następstwami udziału w prowadzonym postępowaniu.

$\mathrm{Na}$ wypowiedzi świadka wpływają nie tylko czynniki obiektywne, niezależne od niego (na przykład warunki spostrzegania, zapamiętywania i odtwarzania spostrzeżeń), lecz także subiektywne, którymi są właściwości fizyczne i psychiczne świadka ${ }^{2}$. Psychologia zeznań i wyjaśnień zajmuje się badaniem wpływu przebiegu tych procesów poznawczych (spostrzegania, zapamiętywania, jak również odtwarzania zapa-

1 www. sjp. pwn.pl/sjp/taktyka (dostęp: 29.09.2017).

2 E. Gruza, Ocena wiarygodności zeznań świadka w prawie karnym. Problematyka kryminalistyczna, Kraków 2003, s. 95-103. 
miętanego materiału), a także innych właściwości psychicznych (procesy myślenia, emocje czy osobowość) na zeznania świadka. Dostarcza również informacji dotyczących czynników, które zaburzają ich prawidłowy przebieg. Wiedza biegłego psychologa może być wykorzystywana w procedurach prawnych do oceny, już w konkretnym przypadku, jakości procesów psychicznych świadka i tym samym może umożliwić organowi procesowemu ocenę wiarygodności świadka i jego wypowiedzi. Natomiast sam organ procesowy, który zgodnie z przepisami proceduralnymi przeprowadza przesłuchanie, powinien odznaczać się posiadaniem chociażby podstawowej znajomości podstaw psychologii dotyczących ogólnego przebiegu i zaburzeń procesów poznawczych. Wiedza ta okazuje się przydatna na wszystkich etapach przesłuchania.

Procesy formowania się zeznań mogą być zaburzone stanami chorobowymi świadka: somatycznymi czy psychicznymi — w takich przypadkach w ocenie ich wpływu na zdolności spostrzegania lub odtwarzania i komunikowania przez niego spostrzeżeń pomocna może okazać się także wiedza biegłego lekarza z zakresu medycyny.

Na podstawie wiedzy psychologicznej i medycznej oraz w granicach obowiązującego prawa również nauka kryminalistyki wskazuje taktyczne zasady przygotowania i przeprowadzania omawianej czynności, a także zasady oceny wiarygodności złożonych przez świadka zeznań. Należy podkreślić, że wiele z tych zasad, które wypowiadane były jedynie na łamach publikacji naukowych, zostało w ostatnich latach usankcjonowane regulacjami prawnymi w odpowiednich procedurach prawnych ${ }^{3}$. Ważnym zaleceniem formułowanym w ramach tej nauki jest wymóg dostosowania sposobu przesłuchania do właściwości psychicznych i fizycznych świadka. Dlatego też w literaturze powoływane są liczne podziały świadków dokonywane według rozmaitych kryteriów. W odniesieniu do poszczególnych kategorii świadków podkreśla się konieczność stosowania odpowiedniej taktyki prowadzenia czynności przesłuchania. Biorąc pod uwagę kryterium wieku, wyróżnia się świadków małoletnich, którzy wymagają specjalnego traktowania z racji ich niedojrzałości fizycznej i psychicznej, która może skutecznie ograniczać możliwość prawidło-

${ }^{3}$ Por. np. J. Sokołowska, Dziecko jako świadek, Warszawa 1959; Z. Czeczot, Kryminalistyczna problematyka osobowych środków dowodowych, Warszawa 1976; V. Kwiatkowska-Darul, Przestuchanie dziecka, Kraków 2001. 
wego przebiegu procesów psychicznych. $\mathrm{Z}$ tego samego powodu tacy świadkowie mogą mieć problem z prawidłowym rozumieniem toczących się procedur prawnych, w których uczestniczą, a także ich znaczenia i tym samym wywoływać negatywne skutki, mogące wpływać na ich zdrowie psychiczne i fizyczne, ale też upośledzić zdolność składania wypowiedzi ${ }^{4}$.

Można stwierdzić, że małoletni to dziecko, którym zgodnie z konwencją o prawach dziecka uchwaloną w 1989 roku przez Zgromadzenie Ogólne Narodów Zjednoczonych jest każda istota ludzka w wieku poniżej osiemnastu lat, chyba że zgodne z prawem odnoszącym się do dziecka uzyska ono wcześniej pełnoletniość ${ }^{5}$. Natomiast według art. 10 $\S 1$ i 2 k.p.c. pełnoletniość uzyskuje się z chwilą ukończenia osiemnastu lat lub z chwilą zawarcia przez małoletniego związku małżeńskiego. Terminy „małoletni” i „dziecko” stosowane są zamiennie zarówno w aktach prawnych, jak i w publikacjach naukowych ${ }^{6}$.

Polskie procedury prawne dają możliwość przesłuchania małoletniego w procedurze karnej, cywilnej czy administracyjnej. W procedurze cywilnej przewidziana jest ponadto instytucja wysłuchania małoletniego odmienna forma wypowiadania się dziecka w postępowaniu cywilnym. Kwestię zeznań świadka w ogóle oraz świadka małoletniego najszerzej reguluje procedura karna. Taka sytuacja uzasadniona jest koniecznością zapewnienia małoletniemu ochrony przed wtórną wiktymizacją, czyli powtórnym przeżywaniem zdarzenia i doznawania w związku z tym cierpień, jakie przeżywa ofiara przestępstwa. Można zauważyć, że tak szerokim regulacjom procesowokarnym towarzyszą liczne publikacje o charakterze prawnym i psychologicznym. Problematyka ta, również

${ }^{4}$ Z. Czeczot, op. cit., s. 102.

5 Konwencja ONZ o prawach dziecka z 23 kwietnia 1964, tekst jedn. Dz.U. z 2014 r. poz. 121 z późn. zm.

${ }^{6} \mathrm{Na}$ przykład w art. $216 \S 1$ k.p.c. ustawodawca stosuje termin „małoletnie dziecko”, a w art. $2161 \S 2$ termin „dziecko”, art. $576 \S 2$ k.p.c. stosuje pojęcie „dziecko”, w art. 430 k.p.c. znajduje się termin „małoletni” — ustawa Kodeks postępowania cywilnego, ustawa z dnia 23 kwietnia 1964 roku, Dz.U. nr 16, poz. 93 z późn. zm. W tytułach publikacji naukowych znajduje się pojęcie małoletniego lub dziecka, np. V. Kwiatkowska-Darul, op. cit.; M. Kornak, Przestuchanie matoletniego jako świadka w procesie karnym, Warszawa 2009; J. Styk, Aspekty prawne wystuchania dziecka w postępowaniu cywilnym, „Dziecko Krzywdzone. Teoria, Badania, Praktyka” 14, 2015, nr 4, s. 9-31. 
w ramach nauki kryminalistyki, omawiana jest głównie w odniesieniu do przesłuchania dziecka jako świadka w postępowaniu karnym, natomiast możliwość przesłuchania go w innych procedurach, a także podjęcia innych form uzyskiwania od niego informacji jest jedynie sygnalizowana. Można mówić o pewnej luce w tym zakresie i formułować w związku z tym postulat zwrócenia uwagi także na czynność przesłuchania w ramach innych procedur prawnych ${ }^{7}$. Każde bowiem przesłuchanie, nie tylko to dotyczące czynu przestępnego, stanowi sytuację stresową, której dziecko może nie sprostać, dla którego może być ona niezrozumiała i tym samym może wywołać negatywne skutki w psychice dziecka, jeśli nie zostanie odpowiednio do niej przygotowane i potraktowane z uwzględnieniem jego wieku i etapu rozwoju oraz potrzeb z nim związanych. Tymczasem w Kodeksie postępowania cywilnego znajdują się znacznie węższe uregulowania prawne dotyczące przesłuchania małoletniego, a także jego wysłuchania. Tej ostatniej czynności poświęconych jest najwięcej publikacji uwzględniających jej perspektywę prawną czy psychologiczną i krytykujących głównie niedostosowanie ich do przepisów prawa międzynarodowego oraz do Konstytucji RP 8 .

Mając to na względzie, celem poniższej publikacji jest próba wskazania zasad taktycznych, odnoszących się do przeprowadzania czynności przesłuchania lub wysłuchania dziecka w innych procedurach prawnych. Aby zrealizować ten cel, w pierwszej kolejności zostaną przedstawione uregulowania prawne o charakterze międzynarodowym, które wskazują na obowiązek ochrony dobra dziecka uczestnika procedur prawnych, a następnie czynność przesłuchania zostanie scharakteryzowana w odniesieniu do procedury cywilnej i administracyjnej.

7 Zob. wystąpienie Rzecznika Praw Dziecka do Ministra Sprawiedliwości z 29 października 2015 roku, http://bip.brpd.gov.pl (dostęp: 2.10.2017).

${ }^{8}$ L. Mazowiecka, Wytyczne Komitetu Ministrów Rady Europy w sprawie wymiaru sprawiedliwości przyjaznego dziecku, „Ius Novum” 2016, nr 3, s. 220-222; J. Zajączkowska, Głos dziecka na wokandzie- o instytucji wystuchania małoletniego, „Palestra” 58, 2013, nr 7-8, s. 59-62. 


\section{Przesłuchanie małoletniego świadka oraz jego wysłuchanie w procedurach prawnych}

Uregulowania prawne o charakterze międzynarodowym dotyczące ochrony dziecka i jego praw znajdują się między innymi w Konwencji Organizacji Narodów Zjednoczonych z 1989 roku o prawach dziecka9, Europejskiej konwencji o wykonywaniu praw dziecka z 1996 roku $^{10}$, Konwencji Rady Europy o ochronie dzieci przed seksualnym wykorzystaniem i niegodziwym traktowaniem w celach seksualnych ${ }^{11}$, w Rezolucji Rady Gospodarczej i Społecznej ONZ z dnia 22 lipca 2005 roku - Wytyczne dotyczące wymiaru sprawiedliwości w sprawach, w których ofiarami lub świadkami są dzieci ${ }^{12}$, dyrektywy Parlamentu Europejskiego i Rady Europy, rekomendacje Komitetu Ministrów Europy czy wytyczne Komitetu Ministrów Rady Europy ${ }^{13}$. Analiza przywołanych regulacji prawnych pozwala sformułować najważniejsze obowiązki

9 Konwencja ONZ o prawach dziecka z 23 kwietnia 1964...

10 Europejska Konwencja o wykonywaniu praw dziecka z 25 stycznia 1996 roku, Dz.U. z 2000 r. Nr 107, poz. 1128.

11 Konwencja Rady Europy o ochronie dzieci przed seksualnym wykorzystaniem i niegodziwym traktowaniem w celach seksualnych, Dz.U. z 2014 r. poz. 1623.

12 Rezolucja Rady Gospodarczej i Społecznej ONZ z dnia 22 lipca 2005 roku, nr 20/2005 - Wytyczne dotyczące wymiaru sprawiedliwości w sprawach, w których ofiarami lub świadkami są dzieci, www.dzieckokrzywdzone.fdds.pl (dostęp: 2.10.2017).

13 Są to np. rekomendacje Komitetu Ministrów rady Europy z dnia 28 czerwca 1985 roku, nr R (85) 11 w sprawie pozycji ofiary w procesie karnym; rekomendacje Komitetu Ministrów Rady Europy z dnia 17 września 1987 roku, nr R (87) 21 w sprawie zapobiegania wiktymizacji i pomocy dla ofiar przestępstw; rekomendacja Komitetu Ministrów Rady Europy z dnia 14 czerwca 2006 roku, nr R (2006) 8 w sprawie wsparcia dla ofiar przestępstw; dyrektywa parlamentu Europejskiego i Rady 2011/93/ UE z dnia 13 grudnia 2011 roku w sprawie zwalczania niegodziwego traktowania dzieci w celach seksualnych i wykorzystywania seksualnego dzieci oraz pornografii dziecięcej; dyrektywa Parlamentu Europejskiego I Rady 2011/36/UE z dnia 5 kwietnia 2011 roku w sprawie zapobiegania handlowi ludźmi i zwalczania tego procederu oraz ochrony ofiar; dyrektywa Parlamentu Europejskiego i Rady Europy 2012/29/UE z dnia 25 października 2012 roku ustanawiająca normy minimalne w zakresie praw, wsparcia i ochrony ofiar przestępstw, wytyczne Komitetu Ministrów rady Europy w sprawie wymiaru sprawiedliwości przyjaznego dziecku z 17 listopada 2010 roku przegląd aktów prawnych, cyt. za: A. Budzyńska, O. Trocha, Dziecko uczestniczace w postępowaniu karnym, Warszawa 2015, s. 14-15; L. Mazowiecka, Wytyczne Komitetu Ministrów Rady Europy z 17 listopa- 
państw i prawa dziecka w omawianym zakresie. Obowiązki te można sformułować w następujący sposób:

— w działaniach dotyczących dzieci, podejmowanych przez publiczne lub prywatne instytucje opieki społecznej, sądy, władze administracyjne lub ciała ustawodawcze mają obowiązek najlepszego zabezpieczenia interesów dziecka;

- we wszystkich sprawach dotyczących dziecka należy zapewnić możliwość wypowiadania się w każdym postępowaniu sądowym i administracyjnym, a wyrażone poglądy przyjmować z należytą wagą, uwzględniając wiek i stopień dojrzałości dziecka; może to czynić wprost lub za pośrednictwem przedstawiciela bądź odpowiedniego organu, zgodnie z procedurą prawa wewnętrznego;

- obowiązek ochrony wrażliwej ofiary przestępstw (ze względu między innymi na wiek, charakter czynu przestępnego oraz niepełnosprawność) przed wtórną i ponowną wiktymizacją, jak również zapewnienia odpowiedniego wsparcia i dostępu do wymiaru sprawiedliwości.

Natomiast do praw dziecka wyrażonych w przywołanych aktach prawnych można zaliczyć:

- prawo do tego, aby dobro dziecka zostało uwzględnione w pierwszej kolejności,

- prawo do uczestnictwa w sprawach go dotyczących,

- prawo do uzyskania informacji o toczącym się postępowaniu, dziecka,

- prawo do wyznaczenia opiekunów w celu ochrony interesów

- prawo do uzyskania odpowiedniej ochrony prawnej podczas udziału w czynnościach dowodowych,

- prawo dostępności do pomocy prawnej.

Jeśli chodzi o unormowania krajowe, to w pierwszej kolejności należy odwołać się do zapisów Konstytucji $\mathrm{RP}^{14}$, w szczególności art. 72 ust. 3, zgodnie z którym w toku ustalania praw dziecka organy władzy publicznej oraz osoby odpowiedzialne za dziecko są obowiązane do wysłuchania i w miarę możliwości uwzględnienia zdania dziecka. Mimo

da 2010 r. w sprawie wymiaru sprawiedliwości przyjaznego dziecku, „Ius Novum” 2016, nr 3, s. 208-227.

14 Konstytucja Rzeczypospolitej Polskiej Dz.U. z 1997 r. Nr 78, poz. 483 z późn. zm. 
występowania w Konstytucji tego zapisu instytucja wysłuchania małoletniego od dawna nie była stosowana ${ }^{15}$.

Jak już wspomniano, najszerszą regulację prawną przesłuchania małoletniego przewidują przepisy procedury karnej. W postępowaniu karnym małoletni świadek może być przesłuchany w normalnym oraz w szczególnym trybie. W związku z tym można wyróżnić następujące kategorie małoletnich świadków uczestniczących w postępowaniu karnym:

1. małoletni pokrzywdzeni przestępstwami z użyciem przemocy lub groźby bezprawnej, które zostały zawarte w rozdziale XXIII k.k. ${ }^{16}$ (Przestępstwa przeciwko wolności), w rozdziale XXV k.k. (Przestępstwa przeciwko wolności seksualnej i obyczajności) oraz w rozdziale XXVI k.k. (Przestępstwa przeciwko rodzinie i opiece), którzy nie ukończyli piętnastu lat w chwili przesłuchania;

2. małoletni pokrzywdzeni przestępstwami z użyciem przemocy lub groźby bezprawnej określonymi w rozdziale XXIII k.k. (Przestępstwa przeciwko wolności), w rozdziale XXV k.k. (Przestępstwa przeciwko wolności seksualnej i obyczajności) oraz w rozdziale XXVI k.k. (Przestępstwa przeciwko rodzinie i opiece), którzy ukończyli piętnaście lat w chwili przesłuchania;

3. małoletni świadkowie w sprawach o przestępstwa $\mathrm{z}$ użyciem przemocy lub groźby bezprawnej z rozdziału XXV lub XXVI k.k., którzy w chwili przesłuchania nie ukończyli piętnastu lat,

4. małoletni świadkowie w sprawach o przestępstwa $\mathrm{z}$ użyciem przemocy lub groźby bezprawnej, zamieszczonych w rozdziale XXV lub w rozdziale XXVI k.k., którzy w chwili przesłuchania ukończyli piętnaście lat;

5. pozostali małoletni pokrzywdzeni,

6. pozostali małoletni świadkowie ${ }^{17}$.

15 Więcej na ten temat zob. J. Zajączkowska, Głos dziecka na wokandzie - o instytucji wystuchania małoletniego, „Palestra” 58, 2013, nr 7-8, s. 57.

16 Ustawa Kodeks karny z dnia 6 czerwca 1997 roku Dz.U. z 1997 r. Nr 88, poz. 553 z późn. zm.

17 S. Skubisz-Ślusarczyk, I. Zieniewicz, Aspekty prawno-kryminalistyczne oraz psychologiczne ochrony zdrowia małoletniego świadka przed negatywnym wptywem czynników procesowych, [w:] Problematyka ochrony życia i zdrowia ludzkiego w prawie karnym, Warszawa 2016, s. 270. Przytoczony podział został opracowany na podstawie 
Podział ten ma znaczenie w odniesieniu do taktyki przesłuchania stosowanej do poszczególnych kategorii małoletnich świadków, która znajduje swoje odzwierciedlenie w przepisach prawnych. Największą ochroną objęci są małoletni pokrzywdzeni i małoletni świadkowie wymienieni w punktach 1-4. Są oni przesłuchiwani w trybie szczególnym wynikającym z art. 185 a-b k.p.k. ${ }^{18}$ Pozostali małoletni pokrzywdzeni i małoletni świadkowie są przesłuchiwani na zasadach ogólnych, jednak i w tym przypadku ustawodawca przewidział instrumenty prawne, których zadaniem jest ich ochrona.

Małoletni świadek uczestniczący w procesie tak jak dorosły świadek ma obowiązki, które mają zapewnić uzyskanie przez organ procesowy wiedzy na temat okoliczności sprawy. Ma również prawa, których celem jest jego ochrona przed negatywnymi skutkami prowadzonego postępowania.

Do obowiązków świadka, których celem jest uzyskanie od niego wiarygodnych i prawdziwych zeznań, należą:

- obowiązek stawiennictwa na wezwanie organu procesowego w określonym miejscu i czasie oraz złożenia zeznań (art. 177 § 1 k.p.k.);

- obowiązek zeznawania prawdy, jednak małoletniego, który nie ukończył siedemnastu lat, nie uprzedza się o odpowiedzialności karnej, gdyż jako niepełnoletni nie ponosi jej.

Jeśli chodzi o prawa przysługujące dziecięcemu świadkowi, których celem jest zapewnienie mu ochrony, to należą do nich:

- prawo do obecności przedstawiciela ustawowego lub faktycznego opiekuna podczas przesłuchania małoletniego świadka, chyba że dobro postępowania stoi temu na przeszkodzie (art. $171 \S 3$ k.p.k.);

- prawo do przesłuchania na odległość przy użyciu urządzeń technicznych umożliwiających przeprowadzenie tej czynności na odległość z jednoczesnym bezpośrednim przekazem obrazu i dźwięku (art. 177 § 1a;

— prawo przesłuchania w miejscu pobytu, jeżeli świadek nie może stawić się na wezwanie z powodu kalectwa lub innej niedającej się pokonać przeszkody (art. $177 \S 2$ k.p.k.);

klasyfikacji sformułowanej przez V. Kwiatkowską-Darul, Przestuchanie małoletniego w postepowaniu karnym, Warszawa 2007, s. 194-195.

18 Ustawa Kodeks postępowania karnego z dnia 6 czerwca 1997 roku Dz.U. z 1997 r. Nr 89, poz. 555 z późn. zm. 
— prawo odmowy zeznań w sytuacjach określonych w art. 182 k.p.k.

- prawo odmowy odpowiedzi na pytania w sytuacjach określonych w art. 183 k.p.k.;

- prawo do przesłuchania $\mathrm{z}$ wyłączeniem jawności $\mathrm{w}$ warunkach określonych $\mathrm{w}$ art. $181 \S 1$ k.p.k.;

- prawo do zwolnienia $\mathrm{z}$ zeznawania $\mathrm{w}$ warunkach określonych $\mathrm{w}$ art. 185 k.p.k.;

- prawo do środków ochrony i pomocy, które zostały określone w art. 3 ustawy o ochronie i pomocy dla pokrzywdzonego i świadka ${ }^{19}$ (ochrona na czas czynności, ochrona osobista, pomoc w zakresie zmiany miejsca pobytu);

- prawo do skorzystania z pomocy psychologicznej na podstawie art. 10 ust. 1 ustawy o ochronie i pomocy dla pokrzywdzonego i świadka. Ważnym uregulowaniem prawnym odnoszącym się do przesłuchania małoletniego są postanowienia art. $192 \S 2$ k.p.k., zgodnie z którymi jeżeli istnieje wątpliwość co do stanu psychicznego świadka, jego stanu rozwoju umysłowego, zdolności postrzegania lub odtwarzania przez niego postrzeżeń, sąd lub prokurator może zarządzić przesłuchanie świadka $\mathrm{z}$ udziałem biegłego lekarza lub biegłego psychologa.

Szczególny tryb przesłuchania małoletniego przewiduje dodatkowe środki jego ochrony określone w art. 185a, 185b, 185d k.p.k.

Artykuł 185a k.p.k. dotyczy przesłuchania pokrzywdzonego przestępstwami z użyciem przemocy lub groźby bezprawnej, które zawarto w rozdziale XXIII k.k. (Przestępstwa przeciwko wolności), w rozdziale XXV k.k. (Przestępstwa przeciwko wolności seksualnej i obyczajności) oraz w rozdziale XXVI k.k. (Przestępstwa przeciwko rodzinie i opiece), który w chwili przesłuchania nie ukończył piętnastu lat. Zgodnie z jego postanowieniami:

— osobę taką przesłuchuje się tylko wówczas, gdy jej zeznania mogą mieć istotne znaczenie dla rozstrzygnięcia sprawy i tylko raz, chyba że wyjdą na jaw istotne okoliczności, których wyjaśnienie wymaga ponownego przesłuchania, lub żąda tego oskarżony, który nie miał obrońcy w czasie pierwszego przesłuchania $(\S 1)$;

19 Ustawa z 28 listopada 2014 roku o ochronie i pomocy dla pokrzywdzonego i świadka, Dz.U. z 2015 r. poz. 21. 
- przesłuchanie przeprowadza sąd na posiedzeniu z udziałem biegłego psychologa $(\S 2)$;

— prokurator, obrońca, pełnomocnik pokrzywdzonego mają prawo wziąć udział w przesłuchaniu; podczas tej czynności może być również obecna osoba wymieniona w art. $51 \S 2$ k.p.k. lub osoba pełnoletnia wskazana przez pokrzywdzonego, jeżeli nie ogranicza to swobody wypowiedzi przesłuchiwanego;

— przebieg tej czynności utrwala się za pomocą obrazu i dźwięku, aby w tej formie odtworzyć ją na rozprawie głównej (§ 3);

- jeżeli małoletni pokrzywdzony w chwili przesłuchania ma ukończone piętnaście lat, przesłuchuje się go w opisanym trybie, jeżeli zachodzi uzasadniona obawa, że przesłuchanie w innych warunkach mogłoby wywrzeć negatywny wpływ na jego stan psychiczny (§ 4).

Artykuł 185b $\S 1$ reguluje czynność przesłuchania małoletnich świadków w sprawach o przestępstwa z użyciem przemocy lub groźby bezprawnej z rozdziału XXV lub XXVI k.k., którzy w chwili przesłuchania nie ukończyli piętnastu lat. Zgodnie z jego unormowaniami świadka, który w chwili przesłuchania nie ukończył piętnastu lat, przesłuchuje się w warunkach określonych w art. 185a $\S 1-3$, jeżeli jego zeznania mogą mieć istotne znaczenie dla rozstrzygnięcia sprawy. Jeżeli świadek w chwili przesłuchania ma ukończone piętnaście lat, przesłuchuje się go w trybie określonym w art. 177 § 1a k.p.k. (przesłuchanie na odległość przy użyciu urządzeń technicznych zapewniających przekaz obrazu i dźwięku), gdy zachodzi uzasadniona obawa, że bezpośrednia obecność oskarżonego przy przesłuchaniu mogłaby oddziaływać krępująco na zeznania świadka lub wywierać negatywny wpływ na jego stan psychiczny.

Kolejne wymogi przesłuchania małoletniego w trybie szczególnym zawarte są w art. 185d $\S 1$ k.p.k., zgodnie z którym przesłuchania przeprowadza się w odpowiednio przystosowanych pomieszczeniach. Na podstawie art. $185 \mathrm{~d} \S 2$ k.p.k. sposób przygotowania przesłuchania oraz warunki, jakim powinny odpowiadać pomieszczenia przeznaczone do przeprowadzenia takich przesłuchań, w tym ich wyposażenie techniczne, mając na względzie konieczność zapewnienia swobody wypowiedzi i poczucia bezpieczeństwa osób, reguluje Rozporządzenie Ministra Sprawiedliwości 
z dnia 18 grudnia 2013 roku w sprawie sposobu przygotowania przesłuchania przeprowadzanego $\mathrm{w}$ trybie określonym $\mathrm{w}$ art. $185 \mathrm{a}-\mathrm{c}$ k.p.k. ${ }^{20}$

Przesłuchania małoletnich powinny być przeprowadzane w specjalnie przygotowanych pomieszczeniach, na które składają się pokój przesłuchań i pokój techniczny. W pokoju przesłuchań podczas czynności może przebywać, oprócz sędziego, biegły psycholog, a za zgodą sądu osoby wymienione w art. $51 \S 2$ k.p.k. albo osoba pełnoletnia wskazana przez małoletniego pokrzywdzonego. Pozostałe osoby przebywają w pokoju technicznym, z którego mogą śledzić czynność, a także formułować pytania do świadka. Pokój przesłuchań może znajdować się w siedzibie sądu, prokuratury, policji lub innej instytucji zajmującej się niesieniem pomocy małoletniemu i ofiarom przestępstwa zgwałcenia. Pomieszczenie to powinno być przyjazne dziecku, wyposażone w meble odpowie nie dla dorosłych oraz dzieci.

Wydaje się, że niektóre taktyczne zasady obowiązujące w ramach szczególnego trybu przesłuchania mogą być stosowane również w odniesieniu do małoletnich świadków przesłuchiwanych w zwykłym trybie, jeżeli sprzyjałyby uzyskaniu wiarygodnych wypowiedzi i chroniły przesłuchiwane dziecko przed stresem związanym z udziałem w tej czynności. Może tu chodzić o zasadę ograniczania liczby przesłuchań, przygotowania małoletniego przez psychologa czy przeprowadzania czynności w specjalnie przygotowanych pomieszczeniach.

Przesłuchanie małoletniego świadka przebiega zgodnie z zapisami kodeksowymi. Nie odbiera się od niego przyrzeczenia (art. 189 k.p.k.), a także nie uprzedza się go o odpowiedzialności karnej za składanie fałszywych zeznań, gdyż nie ponosi on odpowiedzialności karnej za swoje czyny. Należy jednak wytłumaczyć mu potrzebę mówienia prawdy. Czynność rozpoczyna się od zapytania świadka o imię, nazwisko, wiek, zajęcie i miejsce zamieszkania. Ponadto świadka należy uprzedzić o treści art. 182, 183 oraz 185 k.p.k.

Kolejnym etapem przesłuchania jest umożliwienie świadkowi swobodnego wypowiedzenia się $\mathrm{w}$ granicach określonych celem tej czynności, w dalszej kolejności zadaje się pytania uzupełniające, wyjaśniające

20 Rozporządzenie Ministra Sprawiedliwości z 18 grudnia 2013 roku w sprawie sposobu przygotowania przesłuchania przeprowadzanego w trybie określonym $\mathrm{w}$ art. $185 \mathrm{a}-185 \mathrm{c}$ k.p.k. Dz.U. z 2013 r. poz. 1642. 
i kontrolujące wypowiedzi (art. 171 k.p.k.). Świadkowi nie wolno sugerować odpowiedzi na pytania (art. 169 k.p.k.), niedopuszczalne jest wpływanie na wypowiedzi osoby przesłuchiwanej za pomocą przymusu lub groźby bezprawnej, stosowanie hipnozy albo środków chemicznych lub technicznych wpływających na procesy psychiczne osoby przesłuchiwanej albo mających na celu kontrolę nieświadomych reakcji jej organizmu w związku z przesłuchaniem (art. $171 \S 5$ k.p.k.).

Jak wynika z powyższego, regulacja przebiegu i warunków przesłuchania małoletniego świadka w procedurze karnej jest szeroka, zawiera wiele reguł i stanowi wynik procesu dostosowywania jej do wymogów sformułowanych w unormowaniach międzynarodowych oraz postulatów formułowanych przez lata na łamach publikacji naukowych i przez organizacje zajmujące się ochroną dziecka.

Składanie zeznań przez małoletniego świadka przewidziane jest również w procedurze cywilnej. Co prawda Kodeks postępowania cywilnego nie reguluje bezpośrednio czynności przesłuchania dziecka jako świadka, jednak możliwość taką można określić pośrednio na podstawie jego unormowań. Jak wskazano, kwestia przesłuchania świadka nie jest tu tak szeroko regulowana jak w procedurze karnej. Uzasadnia się to tym, że w postępowaniu cywilnym zeznania świadka nie należą do wiodących dowodów, są nimi natomiast dokumenty ${ }^{21}$. Wydaje się jednak, że nie jest to wystarczający argument uzasadniający istniejący stan prawny.

Dopuszczalność przesłuchania świadka w postępowaniu cywilnym uzależniona jest nie od wieku, lecz jego indywidulanych predyspozycji, jak również od poziomu rozwoju psychicznego i fizycznego ${ }^{22}$. Możliwość taką można wywieść z art. 259 k.p.c., zgodnie z którym świadkami nie mogą być osoby niezdolne do spostrzegania lub komunikowania swych spostrzeżeń. Wskazuje na nią ponadto art. 267 k.p.c., który stanowi, że nie składają przyrzeczenia małoletni, którzy nie ukończyli siedemnastu lat. Wyjątkiem jest art. 430 k.p.c., zgodnie z którym w ramach postępowań w sprawach małżeńskich nie można przesłuchać małoletnich, którzy nie ukończyli trzynastu lat, oraz zstępnych stron, którzy nie ukończyli siedemnastu lat. W takich przypadkach można jednak

21 V. Kwiatkowska-Darul, Przestuchanie dziecka..., s. 128.

22 Kodeks postępowania cywilnego. Komentarz do art. 1-729, t. 1, red. A. Jakubecki, Warszawa 2017, s. 466-467. 
przeprowadzić przesłuchanie informacyjne (nazywane wyjaśnieniem lub wysłuchaniem informacyjnym) zgodnie z art. $212 \S 1$ k.p.c. ${ }^{23}$

Kwestią dyskutowaną w piśmiennictwie jest ocena zdolności spostrzegania lub komunikowania swych spostrzeżeń. Ocena ta dotyczy faktycznej i aktualnej w danym czasie zdolności spostrzegania lub komunikowania. W procedurze karnej w razie wystąpienia wątpliwości dotyczących wskazanych zdolności powołuje się biegłego psychologa lub lekarza w celu ich oceny, ostateczną decyzję pozostawiając organowi procesowemu (art. 192 k.p.k.). Wobec braku postanowień w tym zakresie w przepisach procedury cywilnej wysnuwa się wniosek, że tej oceny dokonuje wyłącznie sąd. Powołując się na art. 227 k.p.c., podkreśla się, że niedopuszczalne jest przeprowadzenie dowodu co do innego dowodu, a nie faktów mających istotne znaczenie dla rozstrzygnięcia sprawy ${ }^{24}$. Zdaniem innych brak zapisu o możliwości powołania w tych przypadkach biegłego jest świadomym zamierzeniem ustawodawcy. W związku z tym ocena zdolności zeznawania małoletniego należy tylko do oceny sądu ${ }^{25}$.

Pogląd ten słusznie jest krytykowany przez V. Kwiatkowską-Darul, która za M. Łopatkową podkreśla, że ocena zdolności spostrzegania i komunikowania przez małoletniego należy do wiadomości specjalnych z zakresu psychologii i psychiatrii, nie wystarczy do jej dokonania wiedza ogólna, doświadczenie życiowe czy posiadanie własnych dzieci. Dlatego w przypadku wystąpienia wątpliwości dotyczących prawidłowości wspomnianych procesów poznawczych uzasadnione jest powołanie biegłego na podstawie art. $278 \S 1$ k.p.c. ${ }^{26}$ Właściwe byłoby więc, gdyby ustawodawca wprost przewidział taką możliwość w uregulowaniach kodeksowych.

Do przesłuchania małoletniego odnoszą się w dodatku uregulowania ogólne dotyczące zwykłego świadka. W związku z tym ciążą na nim określone obowiązki zawarte w przepisach ogólnych. Należy do nich obowiązek złożenia zeznań (art. 261 k.p.c.) oraz obowiązek mó-

23 Ibidem, s. 704.

${ }^{24}$ K. Knoppek, Postępowanie cywilne, Warszawa 2015, s. 365.

25 B. Kaczmarek, Matoletni świadek w procesie cywilnym - zagadnienia wybrane, „Przegląd Prawa i Administracji” 81, Wrocław 2009, s. 55-56.

26 V. Kwiatkowska-Darul, Przestuchanie dziecka..., s. 131, cyt. za: M. Łopatkowa, Ścigane z mocy prawa, Warszawa 1986, s. 12. 
wienia prawdy, co w przypadku świadków dorosłych wynika z art. 268 k.p.c. W odniesieniu do małoletnich, którzy nie ukończyli siedemnastu lat, w związku z czym nie ponoszą odpowiedzialności karnej za fałszywe zeznania, obowiązek ten należy mu jedynie wyjaśnić i apelować, aby w trakcie swoich wypowiedzi mówił prawdę.

Dziecko jako świadek ma również uprawnienia, do których należy prawo do odmowy zeznań ze względu na więzy rodzinne ze stronami postępowania zgodnie z art. $261 \S 1$ k.p.c. Małoletni może odmówić odpowiedzi na pytania na zasadach określonych w art. $261 \S 2$ k.p.c. Prawa te stanowią formę ochrony dziecka przed negatywnymi skutkami toczącego się procesu.

Jeśli chodzi o sposób przesłuchiwania, to przed jego rozpoczęciem należy uprzedzić świadka o prawie do odmowy zeznań lub odpowiedzi na pytania. Sama czynność rozpoczyna się od zadania świadkowi pytań dotyczących jego osoby oraz stosunku do stron. Metodyka przesłuchania ma charakter mieszany i składa się z wypowiedzi spontanicznej oraz py$\tan ^{27}$. Następnie składa on zeznanie ustnie, zaczynając od odpowiedzi na pytania przewodniczącego, co i z jakiego źródła wiadomo mu w sprawie, a sędziowie i strony mogą w tym zakresie zadawać pytania (art. $271 \S 1$ k.p.c.). Z artykułu 270 k.p.c. wynika natomiast możliwość powtórnego przesłuchania.

Przepisy Kodeksu postępowania cywilnego przewidują, oprócz przesłuchania małoletniego, także jego wysłuchanie. Zgodnie z art. $216^{1}$ $\S 1$ k.p.c. sąd w sprawach rozpatrywanych w procesie, dotyczących małoletniego dziecka, wysłucha je, jeżeli jego rozwój umysłowy, stan zdrowia i stopień dojrzałości na to pozwala. Paragraf 2 tego przepisu zobowiązuje sąd do uwzględnienia zdania dziecka i jego rozsądnych życzeń stosownie do okoliczności, rozwoju umysłowego, stanu zdrowia i stopnia dojrzałości. Zgodnie z intencją ustawodawcy przywołany przepis ma dotyczyć tylko ustalania w procesie praw niemajątkowych ${ }^{28}$. Natomiast art. $576 \S 2$ k.p.c. stanowi, że w postępowaniu nieprocesowym z zakresu spraw rodzinnych oraz spraw opiekuńczych sąd w sprawach dotyczących

27 V. Kwiatkowska-Darul, Tryb przestuchania w polskich procedurach, [w:] Czynności procesowo-kryminalistyczne w polskich procedurach, red. V. Kwiatkowska-Darul, Toruń 2004, s. 142.

${ }^{28}$ Kodeks postępowania cywilnego..., s. 399. 
osoby lub majątku dziecka wysłucha je, jeżeli jego rozwój umysłowy, stan zdrowia i stopień dojrzałości na to pozwala, uwzględniając w miarę możliwości jego rozsądne życzenia. W sprawie o przysposobienie sąd opiekuńczy powinien wysłuchać przysposabianego, który nie ukończył trzynastu lat, jeżeli może on pojąć znaczenie przysposobienia (art. 118 k.r.o.) $)^{29}$.

W literaturze podkreśla się, że ocena stanu zdrowia, rozwoju umysłowego oraz stopnia dojrzałości w razie wątpliwości powinna być poprzedzona opinią biegłego psychologa, pedagoga lub lekarza psychiatry, neurologa czy pediatry ${ }^{30}$. Tak jak w przypadku wysłuchania w postępowaniu procesowym taktyczną zasadą jest przeprowadzenie go poza salą posiedzeń sądu na posiedzeniu niejawnym. Zgodnie z $§ 154$ ust. 1 rozporządzenia Ministra Sprawiedliwości — Regulamin urzędowania sądów ${ }^{31}$ wysłuchanie, jeśli to możliwe, odbywa się w przeznaczonym do tego celu pomieszczeniu. Jeśli nie ma takiego pomieszczenia w siedzibie sądu, można je przeprowadzić poza budynkiem sądu w pomieszczeniu, którym dysponują organizacje pozarządowe zajmujące się ochroną praw dzieci.

Należy zaznaczyć, że wysłuchanie dziecka nie jest traktowane jako dowód, stanowi natomiast pomocniczą instytucję o charakterze techniczno-procesowym, która służy do uzyskania przez sąd wyjaśnień i oświadczeń potrzebnych do rozstrzygnięcia danej sprawy ${ }^{32}$. Jej celem jest zapoznanie się sędziego ze stanowiskiem dziecka, a nie zebranie materiału dowodowego $^{33}$. Dlatego też z czynności wysłuchania sporządza się notatkę urzędową zgodnie z art. $157 \S 3$ k.p.c. oraz $§ 154$ ust. 2 regulaminu urzędowania sądów.

29 Ustawa z dnia 25 lutego 1964 roku Kodeks rodzinny i opiekuńczy, Dz.U. z 1964 r. Nr 9, poz. 59 z późn. zm.

30 J. Styk, Aspekty prawne wystuchania dziecka $w$ postępowaniu cywilnym, „Dziecko krzywdzone. Teoria, badania, praktyka” 14, 2015, nr 4.

31 Rozporządzenie ministra sprawiedliwości Regulamin urzędowania sądów powszechnych z 23 grudnia 2015 roku Dz.U. z 2015 r. poz. 2316.

32 J. Styk, op. cit., s. 24, cyt. za: K. Markiewicz, Dowodzenie w postępowaniu nieprocesowym, [w:] Dowody w postępowaniu cywilnym, red. Ł. Błaszczak, K. Markiewicz, E. Rudkowska-Ząbczyk, Warszawa 2010.

33 J. Styk, op. cit., s. 26. 
Również przepisy Kodeksu postępowania administracyjnego ${ }^{34}$ zawierają uregulowania dotyczące dowodu z zeznań świadka. Tak jak w przypadku procedury cywilnej brakuje tu ograniczenia związanego z wiekiem. Ustawodawca wskazuje, że świadkiem nie może być osoba niezdolna do spostrzegania lub komunikowania swoich spostrzeżeń (art. 82 k.p.a), ocena zaś tych zdolności lub ich braku należy do organu orzekającego lub organu przyjmującego zeznania świadka ${ }^{35}$. Jest to przepis analogiczny do art. 259 k.p.c., w związku z czym do wyrażonego poglądu można odnieść przedstawioną wcześniej krytykę ${ }^{36}$.

Świadek w postępowaniu administracyjnym, więc i małoletni, ma obowiązek zeznawania, co wynika z jego uprawnienia odmowy zeznawania lub odpowiedzi na pytania w sytuacjach określonych w art. 83 $\S 1$ i 2 k.p.a. Przed rozpoczęciem przesłuchania świadka uprzedza się o odpowiedzialności za fałszywe zeznania, a wyjątkiem są tu małoletni, którzy nie ukończyli siedemnastu lat, ponieważ nie ponoszą oni odpowiedzialności karnej. Samego przebiegu przesłuchania ustawodawca nie reguluje.

Jak wynika z powyższego, ograniczona regulacja sposobu przeprowadzania czynności przesłuchania i wysłuchania małoletniego w postępowaniu cywilnym i administracyjnym nie zapewnia należytej jego ochrony przed negatywnymi skutkami toczącego się postępowania, które mogą mieć, niezależnie od charakteru sprawy, różną postać: lęku, poczucia winy, niesprostania oczekiwaniom bliskich, bycia w związku z tym ofiarą, zagubienia z powodu nierozumienia toczących się czynności, niepokoju czy depresji. Mogą to być również objawy somatyczne będące wynikiem przeżywanego stresu, takie jak bóle głowy, pleców, podwyższone ciśnienie, choroby serca, obniżenie odporności organizmu itp. ${ }^{37}$

Ograniczonej ochrony dziecka nie można tłumaczyć charakterem spraw prowadzonych w ramach różnych procedur prawnych. W każdym postępowaniu trzeba zapewnić mu należytą ochronę. Dlatego za słuszny

34 Ustawa Kodeks postępowania administracyjnego z 14 czerwca 1960 roku Dz.U. z 1960 r. Nr 30, poz. 168 z późn. zm.

35 B. Adamiak, J. Borkowski, Postępowanie administracyjne i sądowo-administracyjne, Warszawa 2014, s. 208.

36 V. Kwiatkowska-Darul, Tryb przestuchania w polskich procedurach..., s. 145.

37 V. Kwiatkowska-Darul, Przestuchanie małoletniego..., s. 257. 
należy uznać postulat o wprowadzenie szerszych regulacji prawnych odnośnie do przesłuchania małoletniego, a także jego wysłuchania w postępowaniu cywilnym. Na brak regulacji prawnych w tym zakresie zwrócił uwagę w 2015 roku Rzecznik Praw Dziecka w piśmie skierowanym do Ministra Sprawiedliwości z 29 października 2015 roku. W jego ocenie

standard ochrony dziecka przewidziany w przepisach proceduralnych powinien znaleźć odpowiednie odzwierciedlenie w Kodeksie postępowania cywilnego, ponieważ także w postępowaniu cywilnym dzieci zasługują na szczególne traktowanie w trakcie czynności procesowych. Na sądzie bowiem ciąży obowiązek dbałości, aby osobisty udział dziecka w postępowaniu nie miał ujemnych następstw natury społeczno-wychowawczej albo aby tego rodzaju następstwa były ograniczone do minimum ${ }^{38}$.

\section{Taktyczne zasady przesłuchania małoletniego świadka oraz jego wysłuchania}

Poczynione rozważania skłaniają do wskazania na pewne uniwersalne zasady taktyczne w oparciu o postulaty wysuwane przez doktrynę oraz uregulowania prawne z zakresu procedury karnej, którymi mógłby posiłkować się organ procesowy przesłuchujący dziecko w procedurze cywilnej czy administracyjnej. Pomocne w tym względzie będą niektóre zasady taktyczne odnoszące się do przesłuchania $\mathrm{w}$ procedurze karnej, jak również te, które formułowane są w wielu publikacjach psychologicznych i kryminalistycznych ${ }^{39}$. W odpowiednim zakresie mogą być one stosowane różwnież podczas wysłuchania w postępowaniu cywilnym, którego regulacja w przepisach procedury cywilnej jest krytykowana i oceniana jako niewystarczająca oraz w pewnym zakresie niewłaściwa ${ }^{40}$.

38 Wystąpienie Rzecznika Praw Dziecka do Ministra Sprawiedliwości z 29 października 2015 roku.

39 Mimo stosunkowo szerokiego uregulowania kwestii przesłuchania małoletniego w przepisach procedury karnej wiele innych zasad taktycznych formułowanych jest przez kryminalistyków i psychologów.

40 Por. M. Cieśliński, Praktyka sądowa w zakresie wystuchiwania małoletnich $w$ postepowaniach cywilnych $w$ kontekście idei przyjaznego wystuchiwania dziecka. Raport z badania, Instytut Wymiaru Sprawiedliwości, Warszawa 2015. Autor opisuje badania ankietowe wśród sędziów, które dotyczyły instytucji wysłuchania małoletniego. 
Pierwszą uniwersalną zasadą taktyczną jest odpowiednie przygotowanie się do przesłuchania przez organ procesowy, ponieważ daje ono gwarancje jego sprawnego i profesjonalnego przeprowadzenia. Ważny jest sam moment podejmowania decyzji o przesłuchaniu małoletniego. Należy więc zastanowić się, czy wybrany moment przesłuchania jest odpowiedni, czy został zgromadzony wystarczający materiał dowodowy, który dawałby podstawy do sformułowania odpowiednich pytań do świadka, a także czy istnieje możliwość ustalenia okoliczności zdarzenia poprzez inne czynności dowodowe ${ }^{41}$.

W ramach czynności przygotowawczych należy dokładnie zapoznać się z materiałem zebranym w sprawie, ponieważ jego dobra znajomość daje podstawy do zaplanowania odpowiednich pytań, które organ procesowy będzie kierować do dziecka. W tym celu należy również podjąć starania w celu uzyskania informacji o małoletnim, o jego stopniu rozwoju, zainteresowaniach, wrażliwości czy o innych jego cechach ${ }^{42}$. Informacji takich można zasięgnąć na przykład od rodziców małoletniego, psychologa czy lekarza. Mogą one być pomocne w podjęciu decyzji, czy przesłuchanie lub wysłuchanie przeprowadzić z udziałem na przykład biegłego psychologa. Postuluje się nawet, aby wymóg udziału biegłego w przesłuchaniu był obowiązkowy ${ }^{43}$. Uzasadniona może być również konsultacja wstępna z psychologiem na temat trwania czynności, ewentualnie sposobu zadawania pytań ${ }^{44}$. Cenna może okazać się sama rozmowa dziecka z psychologiem w celu wytłumaczenia, na czym będzie polegała czynność przesłuchania lub wysłuchania, jak będzie przebiegać, jaki jest jej cel, jak trzeba się zachować w trakcie czynności, a przede wszystkim po to, aby zniwelować stres i oswoić to, co jest dla małoletniego nieznane $e^{45}$.

Wyniki badań wskazują, że w praktyce wysłuchanie jest przeprowadzane dosyć rzadko w różny sposób. Biorąc pod uwagę praktykę sądową, formułuje prawidłowy model przeprowadzania tej czynności.

41 S. Skubisz-Ślusarczyk, I. Zieniewicz, op. cit., s. 271.

42 T. Hanausek, Kryminalistyka, Warszawa 2009.

43 Wystąpienie Rzecznika Praw Dziecka do Ministra Sprawiedliwości z 29 października 2015 roku.

44 S. Skubisz-Ślusarczyk, I. Zieniewicz, op. cit., s. 273.

45 Ibidem. 
Kolejnym zaleceniem dla organu procesowego jest dążenie do ciągłego poszerzania wiedzy przez osoby przesłuchujące w zakresie psychologii czy psychiatrii, co pozwoli na zrozumienie specyfiki procesów psychicznych odpowiednich dla określonego etapu rozwoju dziecka. Posiadanie takich wiadomości może ułatwić nawiązanie kontaktu z dzieckiem, jak również przeprowadzenie samej czynności przesłuchania ${ }^{46}$.

Istotny jest także wybór właściwego czasu przesłuchania, a także stworzenie odpowiednich warunków w miejscu, w którym przesłuchanie będzie przeprowadzane, tak aby małoletniemu zapewnić poczucie bezpieczeństwa $\mathrm{w}$ trakcie przeprowadzania tej czynności ${ }^{47}$. Przesłuchanie lub wysłuchanie

powinno odbywać się w warunkach jak najbardziej sprzyjających otwarciu się dziecka i zapewnienia mu bezpieczeństwa, w specjalnie do tego przystosowanych pomieszczeniach, spełniających określone wymogi techniczne i formalne, zapewniające maksimum prywatności - na wzór przyjaznych pokoi przesłuchań, zwanych „niebieskimi”, wykorzystywanych przy przesłuchaniu dziecka w postępowaniu karnym. Obecnie „niebieskie pokoje" są obowiązkowo wykorzystywane w procesach karnych, natomiast w sprawach cywilnych kwestia ta zależy nadal od dobrej woli sędziów, którzy nierzadko z takiej możliwości nie korzystają ${ }^{48}$.

Ważnym elementem przygotowania przesłuchania lub wysłuchania jest również przygotowanie do tej czynności rodziców dziecka, wyjaśnienie im celu, zobowiązane ich do zaniechania wpływania na dziecko czy nierozpytywanie dziecka o przebieg wysłuchania po jego zakończeniu ${ }^{49}$.

Stworzenie chociażby ramowego planu przesłuchania, czyli ustalenie pytań, które będą kierowane do dziecka, a także ich kolejności, to następna zasada, której należy przestrzegać. Dobra znajomość sprawy wpływa na możliwość pełnej kontroli nad spokojnym przebiegiem omawianych czynności ${ }^{50}$.

46 M. Kornak, op. cit., s. 123.

47 Art. $2161 \S 2$ k.p.c., art. 576 § 2 k.p.c.; V. Kwiatkowska-Darul, Przestuchanie dziecka..., s. 176-179; M. Kornak, op. cit., s. 131-139.

48 Wystąpienie Rzecznika Praw Dziecka do Ministra Sprawiedliwości z 29 października 2015 roku.

49 A. Budzyńska, Wystuchanie dziecka w postępowaniu cywilnym - perspektywa psychologiczna, „Dziecko Krzywdzone. Teoria, Badania, Praktyka” 14, 2015, nr 4, s. 49.

50 V. Kwiatkowska-Darul, Przestuchanie dziecka..., s. 173-174; M. Kornak, op. cit., s. $125-126$. 
Przed rozpoczęciem samego przesłuchania uzasadnione wydaje się, aby przesłuchujący nawiązał kontakt z dzieckiem poprzez przeprowadzenie z nim swobodnej rozmowy wolnej od oschłości, powinien też unikać zwrotów, które onieśmielałyby małoletniego, które byłyby dla niego niezrozumiałe, nie powinien też zwracać się do dziecka per, ,świadek" "51. Organ procesowy powinien też wskazać na sens i cel czynności, potrzebę mówienia prawdy, a także konieczność sygnalizowania, jeśli formułowane pytania czy sytuacje będą niezrozumiałe. W sposób niezbyt oficjalny powinien zapytać o imię, nazwisko, a także o strony postępowania, a w sytuacji gdy jest to uzasadnione, wytłumaczyć, że dziecko może odmówić składania zeznań lub odpowiedzi na pytania ${ }^{52}$. W ramach etapu właściwego zeznawania sąd powinien czuwać nad przebiegiem zadawania pytań przez strony i nie dopuścić do sytuacji, które mogłyby negatywnie wpłynąć na dziecko lub je zastraszyć. Pytania powinny być sformułowane w sposób precyzyjny i zrozumiały (im młodsze dziecko, tym bardziej zasada ta powinna być stosowana), powinny mieć prostą konstrukcję gramatyczną, dawać możliwość udzielenia konkretnych odpowiedzi, zważywszy na wiek dziecka, nie należy stosować pojęć nieostrych, zbyt trudnych ${ }^{53}$. Nie powinny to być pytania sugerujące odpowiedź ${ }^{54}$. Ważny jest również ton ich wypowiadania - neutralny, spokojny, pozbawiony złośliwości czy chęci ośmieszenia dziecka. Po odczytaniu małoletniemu świadkowi protokołu, a także po wysłuchaniu dziecka należy porozmawiać z nim na temat niezwiązany ze sprawą, zapewnić, że jego wypowiedzi są pomocne dla organu procesowego i że dobrze wypełniło swoje zdanie, a następnie zapytać o samopoczucie i podziękować za udział w czynności przesłuchania lub wysłuchania ${ }^{55}$.

Jeszcze jednym zaleceniem mającym na celu ochronę dobra dziecka, które należy mieć na uwadze w sytuacji przesłuchiwania czy wysłuchiwania dzieci, jest unikanie wielokrotnie przeprowadzanych czynności. Uzasadnieniem tego ograniczenia jest również sama praktyka sądowa, z której wyni-

51 T. Hanausek, op. cit., s. 209.

52 Ibidem.

53 M. Kornak, op. cit., s. 199-200.

54 B. Hołyst, Kryminalistyka, wyd. 12, Warszawa 2010, s. 1107-1108.

55 A. Budzyńska, op. cit., s. 50. 
ka, że najbardziej wiarygodne wypowiedzi uzyskuje się za pierwszym razem, kolejne natomiast stanowią już powtórzenie tych pierwszych relacji ${ }^{56}$. Istotą reguł odbierania wypowiedzi od małoletniego jest indywidualne podejście do każdego dziecka uczestniczącego w procedurze prawnej. Tylko ono może zapewnić równocześnie uzyskanie od niego wiarygodnych informacji i ochronę jego dobra ${ }^{57}$, między innymi poszanowania jego godności, poglądów, zdrowia psychicznego i fizycznego czy równego traktowania. Nie ma w związku z tym jednej metody przesłuchiwania czy wysłuchiwania dzieci. Każdorazowo należy dokonać świadomego jej wyboru i w razie konieczności skorzystać z dostępnych narzędzi, jakie dają unormowania prawne, a także dorobek nauki w tym zakresie.

\section{Legal and forensic science issues of children hearing in Polish law proceedings}

\section{Summary}

The children witness hearing belongs to special trial activities and requires a special approach of judges, prosecutors, policemen who are responsible for its conduct. The most extensive regulations are those concerning witness hearing in a criminal proceding. In civil and administrative procedure the regulations are evaluated as insufficient. The person questioning the children has to have psychological and forensic science knowledge. Those fields of science formulate the tactical rules of child hearing. Their first aim is the protection of children from negative results of participation in law trials and the second aim is to receive trusted information concerning circumstances of law case. This publication is presenting the tactical rules which can be used in law proceedings.

Keywords: children witness, child hearing, forensic science, psychology, child protection in law proceedings.

56 B. Hołyst, op. cit., s. 1109; J. Styk, op. cit., s. 26-27.

57 A. Budzyńska, O. Trocha, op. cit., s. 84-92. 